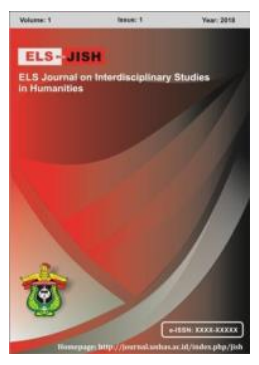

\title{
ELS-JISH
}

ELS Journal on Interdisciplinary Studies on Humanities

Volume 3 Issue 1, 2020

ISSN (print) : 2621-0843

ISSN (online) : 2621-0835

Homepage : http://journal.unhas.ac.id/index.php/jish

\section{Reflective Teacher Journal to Develop Teacher's Professionalism}

\author{
Anjar Nur Cholifah ${ }^{1}$, Abdul Asib $^{2}$, Suparno $^{3}$ \\ 1anjarcholifah@gmail.com
}

\begin{abstract}
To be good a teacher, a teacher must incessantly improve her/his teaching practice and skill/knowledge to produce and keep the academic quality. Mechanically, a teacher requires to concern a particular method/ technique or strategy and use a certain tool/type to fulfill the benchamark of excellence in teaching. Hence, reflection is substantial as one of the indispensable approaches that can be practiced to direct teacher's performance becomes more experienced. In teaching, the term reflection refers to the opportunity of teachers to think back critically after the teaching-learning process. Previous studies that have been conducted to observe the efficiency of teacher journal in the education field. Conversely, only a few kinds research explored teacher's perceptions toward the utilization of the teacher's journal. Likewise, this research was located in Indonesia and engage an in-service EFL teacher of Junior High School to accomplish the gap. It intended at determining the parts reflected from the teacher journal. Moreover, to investigate the research problems, the researcher used an in-depth interview to explore the teacher's experience in utilizing teacher diary. Consequently, this study employed a qualitative method since it was considered as the appropriate design to accomplish the research. The researcher concluded that the teacher has a positive perceptions related to the teacher's diary/teacher's journal. It gives precious involvement for English teachers to be more experienced and professional to help students in mastering English skills and help the teacher to do reflection in order to make a better teaching practice for the next English teaching.
\end{abstract}

Keywords: Reflective Practice, Teacher Journal, Professional Developmen

How to cite: Cholifah, A. N., et al. (2020). Reflective Teacher Journal to Develop Teacher's Professionalism. ELS Journal on Interdisciplinary Studies in Humanities, 3(1), 22-30. DOI: http://dx.doi.org/10.34050/els-jish.v3i1.9517.

\section{Introduction}

EFL teachers are in a never-ending effort to meet the requirements of the curriculum and accomplish students' needs for their better careers. Thus, in a strive to complete such a duty, EFL teachers have to be dependable and knowledge-grounded of the updated teaching-learning methods, approaches, or strategies. Incidentally, teachers need to employ different strategies, evaluate and reflect toward their teaching practices in ord to be professional teachers. In addition, Sari, et. al (2019) stated that EFL teachers can also create language patterns that can be understood by students .

\footnotetext{
${ }^{1,2,3}$ Universitas Sebelas Maret, Indonesia.
} 
Therefore, teachers require todo a reflection. In the education field, the term reflection leads to reflective teaching/ reflective practice. This can be one of the solutions for the teachers to do some evaluations toward their teachinglearning process in order to reach the situation in which students could understand and comprehend what they learn and become more master in every former element of English language. Several studies investigated that there are some existing tools can be utilized to reflect teaching practice: peer observation, students' feedback, teacher's journal/diary, and audio/video recording (Tosriadi, 2018; Lee, 2007; Azizah, 2018, Soisangwarn \& Wongwanich, 2014).

Reflective journal writing is one of the reflection tools for the teacher to reflect his/her teaching that is used in a classroom activity. It has a noteworthy impact on the teacher to promote teacher professional development. To point out, reflective teaching is an approach could be used to achieve professional development in teaching (Bailey, Curtis \& Nunan, 2011). The previous study in Indonesia is Astika (2014) who investigated 40 journals of teaching reflection yield by 40 Indonesian pre-service English teachers. The pre-service teachers were commanded to write teaching reflections about 500-600 words. It should include some issues relating to teaching consist of lesson plans, materials, classroom management, and activities. They were in the teaching practicum period of the exploration in which every student teacher must teach English in a school that is close to the university. That research informed that teaching journals written by pre-service English teachers enclose more reflection on the individual and contextual domains of teaching. It emerged that pre-service English teachers were more affected with their judgments, response, and teaching behavior concerning to the teaching-learning activity in the classroom and how the classroom contexts concerned, revealed or influenced their teaching practice. Even there are several studies investigated reflective teacher journals, but only a few studies explored the teacher's perception in utilizing theteacher journal to do reflection in a detailed way. With those in mind, this study focused on examining several elements of teaching reflected and written in journal writing. To disclose something recent for the specific field, this research contained an English teacher as the participant to reveal the role of reflective teaching in the English classroom.

Moreover, Reflection, as the original term of reflective practice, is categorized as a strategy to increase teaching quality for the teachers. Dewey is the first person who coined the notion of reflective practice. He defined reflection as "active, persistent, and careful consideration of any belief or supposed form of knowledge in the light of the grounds that support it which intends constitutes reflective thought" (Dewey, 1933). For Dewey, reflection has a function to transform the condition of insignificance, uncertainty, inconsistency, and disturbance into understandable, consistent, developed, and harmonious one (Dewey, 1993, as stated in Lyons, 2010). Hence, it can be concluded that reflective practice is a transformation from the bad condition to a good condition in the teaching-learning process. Another key point in defining reflective practice was Schon's (1983) perspective on reflective practice. Schon coined phrases such as "reflection in action" and "reflection on action" to describe how experiences, solve all the problems, and allow people to respond to the commands of their profession. Further, Farrell (2012) explained more 
about reflection-in-action called as an interactive reflection means the process of teacher's thinking towards teaching-learning activities while on the job. So, the teacher does reflection while teaching-learning activities is on process. In reflection-on-action, the educators think their previous teaching whether there is any problem or not and also to find out another option to solve it. The last, reflection-for-action or anticipatory means teachers consider the situation or problem will happen in the future teaching. Besides, the reflection involves three aspects to be a reflective teacher. Those substantial points of view are open-mindedness, whole-heartedness, and responsibility (Farrell, 2015).

Consequently, reflective journal writing, yet, is one of the most frequently used around the world. Writing reflective journals is presumed to improve student teachers' critical thinking since it assists them to think differently of teaching in light of individual and contextual issues and re-examine their understanding of their teacher selves throughout a process of the invention (Farrell, 2004; Lee, 2007). Furthermore, reflective journal writing, among other things, helps teachers discover their strenghts and weaknesses, look for improvements, and link their existing knowledge with the updated information. In addition, there are four major components of pedagogical base noticed by teachers: First, knowledge of the language and related disciplines followed by knowledge of ELT theories, skills, and techniques. Then, knowledge of context and social relations followed by knowledge of class time, and learning management (Moradkhani, Akbari, Samar, \& Kiany, 2013). In conclusion, the management of language, learning, knowledge, and classroom are categorized under the term of teacher's pedagogical knowledge base which is significantly reflected in the teacher's journal.

Professional development is a term that cannot be separated from the educational field and $21^{\text {st }}$ century learning. Guskey (2000) defined professional development as practitioners' opportunity in the way of seeking particular techniques to improve teaching practices and students' learning. Teaching improvement can be indicated when the practitioners are involved in such activities that seek to enhance knowledge and skills, which may also contribute to their personal, social, and emotional growth (Desimone, 2015). Consequently, teaching practices lead to a major improvement in teaching abilities and intelligence and teacher has also a significant influence on student achievement. Hence, practicing reflective practice should be developed by the teacher to promote professional development. Furthermore, the use of reflection in teacher professional development is based on the basis that the teachers may improve their teaching practice by methodically reflecting on experiences (Farrell, 2015).

To sum up, through this study, the researchers expect to find new insights from the teacher who practiced the teacher's journal as part of his/her teachings. Those, to reach the purpose, the research question of this study formulated as follow: 1) What are the constituents of the pedagogical knowledge base being reached by an in-service EFL teacher in her reflective teacher journal? 


\title{
2. Method
}

This research explored the phenomenon that occurred in utilizing the teacher's reflective journal in the classroom. The research question posed in this study lead the researcher to carry a qualitative case study to investigate the in-depth phenomenon within its real context (Yin, 2018). Case study research is most likely to be appropriate for "how" and "why" questions. Due to the emergence of any possible findings, Yin (2018) also suggests conducting case study research to cope with more variables of interest, multiple sources of evidence and benefits from the prior development of theoretical propositions.

In this research, the researcher investigated the components of the pedagogical knowledge base being realized by an in-service EFL teacher in her reflective teacher journal. The data gained by did the interview and recorded it. The interview is needed to get the detail information related to the topic of the study. Furthermore, the interactive model by Miles, Huberman, \& Saldana, (2014) was applied to analyze the data which consists of three stages: (1) data condensation, (2) data display, and (3) drawing and verifying conclusion. The participant of this study is an in-serviceEFL teacher in one of Junior High Schools in Lampung. The participant of this study was purposively selected in accordance with the experiencing of utilizing the teacher journal in doing reflection.

\section{Finding and Discussions}

The pedagogical knowledge of the teacher bases reflected and written in teacher journal was depicted below:

\begin{abstract}
"Actually, there are some factors that can be revealed in teaching-learning activity. The important thing is to discover the fault/weaknesses of teaching methods, steps, techniques, strategies, media, etc. It is to find the best solution toward the problems, so the same conditions will not occur anymore in the next meeting. Moreover, the teacher also should pay attention and do an evaluation related to students' attitudes. Due to the importance of this aspect, teacher should know the students' needs, feelings, and responses in order to help them to achieve the learning outcomes. The students demanded to have a good attitude toward the teaching-learning process, thus the teacher should do an evaluation related to teaching practice that appropriates with students' points and needs. With those in mind, it is hoped in creating a better classroom environment."
\end{abstract}

The above-mentioned data lead the point of view that pedagogical components in teaching reflected such as teaching methods, steps, techniques, strategies and the attitude of students also. By utilizing teacher journal, the teacher could write and make a note related to some activities that confronted her from classroom activities and according to this act, teacher could know several aspects in teaching needed to increase students' performance, behavior, teaching strategies, management of the classroom, students with special needs, and the difficulties on maintaining journal entrances (Chien, 2013).

Furthermore, the researcher investigated the teacher's opinion in a detailed way, and it is found that the teacher in one situation taught speaking 
subject. Though there were some students who were so excited in speaking subject, yet others felt nervous and did not want to speak louder, most students still got difficulties and felt shy in saying something. However, the teacher tried to use a media like video conversation and emoticon box. She believed that following the speakers' say could increase students' motivation and attention. Students would repeat the native speaker and tried to speak as same as the native. It made the class so alive. Moreover, the teacher asked the student to do role play, then they had to role the conversation with their peer, even there were some students who felt shy, but they still did the conversation due to the support from their friends. It would be different if the teacher asked them one by one, they felt that all eyes kept on them and they were nervous to speak. Additionally, the teacher used the emoticon box to make students speak, it was an interesting media because the students should guess what the expression was. By using those media, the teacher was really sure it could increase the students' motivation and classroom activity could run so well. She could improve the way of teaching at that time. Both strenghts and weaknesses of utilizing the media were written in her journal directly.

The description of the situation above indicates that engaging the students and making them pay attention to the speaking subject can be done by showing the video conversation or any related elements based on the students' interest. Moreover, the speaking subject becomes interactive since the students enthusically respond to the native's conversation as they find that what is shown is interesting. Additionally, related to teaching English, the researcher explored the teacher's perception from the interview.

"Being an English teacher is not an easy thing. I almost wrote all the challenges confronted by me in my journal. I tried to write directly, at that time, when I feel that situation should be written. I doubt I will forget it if not writing directly. Especially when discussion sessions, sometimes there are students who do not interested enough and just keep silent, so I write their names and I asked them directly. I should know their intention of being silent. Or in another situation in the reading subject, the students are very crowded due to the discussion of some difficult vocabularies, though it is not a discussion session. So I will write in my journal. By using the journal, I could remember the activities before and keep the focus on students' activities."

The statement mentioned by the teacher above indicates that the teacher wrote the activities happen in her journal were the situations or students' condition that was important to be written. It can be assumed that there are three pedagogical components reflected by the teacher. Those are classroom management, the students' performance, and lesson plan. Those pedagocial components are categorized as class time knowledge and learning management. Moreover, the teachers should comprehend the knowledge of lesson planning, and classroom and time management as well as differences in teaching-learning among language teachers (Moradkhani, et.al, 2013). Besides, in the lesson plan, Moradkhani also stated that language teachers need to reflect on the appropriate lesson materials for the students in the teachinglearning process. In addition, the participant of this study did not only write the important thing in her journal while on the job, but also did an evaluation at her 
home. She thought why did can happen, and how to solve the situations. Besides, she also could discuss with other teachers to determine the alternative solutions related to the problems she confronted. For instance, when the students were so crowded and she did not have an idea to make the situation ran well, usually the teacher would ask other teachers how to deal with it. Further, related to the lesson material, the teacher would learn from the previous teaching about the students' problems. As an illustration, in the reading session, it is very often that the students will meet some difficult vocabularies. How to pronounce it, and what the definition is. Before teaching, she would prepare powerpoint about the difficult words, and add the correct pronounce followed by the definition. It will be an interesting way to start the reading section. To sum up, the participant had written some pedagogical components that can be reflected in her teaching. The same as the idea from Chien (2013) who said that all elements had been reflected, yet for students for special needs was rather revealed because there ire no disability students.

On the other hand, in this study, the researcher also asked related to the problems faced by the teacher in using the teacher journal to do a reflection. Based on the interview result, the teacher said that she lacks of time. She did not have enough time to write all the activities happen in the classroom. Further, the teacher did not only focus on journal but also the class activity. Besides, she also should think back critically about the method she used in teaching whether it is appropriate enough or not. The teacher also must be able to solve the problem happen in the teaching-learning process and plan another way to teach in order to make a better teaching practice. With those of situations, the teacher only had a little time to write and make a note in her journal. By all means, the participant needed more time to write the students' condition, the classroom activity, and students' difficulty as her reflection in teaching. The result of this research was in line with the previous study that observed some pre-service teachers in writing teacher journals. It was found that the participants argued that writing journal was time-consuming, it was also rather difficult to utilize (Astika, 2014). Moreover, another study comes from Degago (2007) who found that the participant in his study agreed that writing journal strongly helped them to do a reflection but wasting time. The consideration that is mentioned by the informant can be seen below:

"The difficult part of utilizing teacher journal is about time. I do not really focus on writing the situation in the classroom or make a note about students' response. I focus on the teaching-learning process and delivering the material. It is rather difficult for me to divide time in a writing journal and focus on the class"

Therefore, the participant suggested a solution to write the keyword or some important activities that should be remembered in order to save time. It is more efficient to break the limited time. Further, the teacher also could use another type of reflective practice like video recording. According to Abednia (2013), he claimed that recording teaching-learning activity could get the rich data continued by writing the teacher journal. Further, Farrell, 2007; and OrlandBarak \& Yinon, 2005) claimed that writing journals regularly is highly recommended because it could help teachers reflect their own teaching, discover teachers' own beliefs and practice, and examine their own practice. 


\section{Conclusion}

Teachers need to look at several aspects that can assist them to increase their knowledge and skill in English to be a professional teacher. Reflection, in specific, is a model that is significantly more noteworthy to engage an English teacher in promoting professional development. Reflection means English teachers are necessary to look back on what they have done in the classroom, how the process of teaching-learning activity, how the students' response, why that could occur, and others. At this point, English teachers must think back significantly and connect to the English lesson. As a result, EFL teachers could utilize their journal/diary to reveal the English lesson. Teacher's' journal is valuable for educators since it can be employed in teaching and provides several feedbacks relating to teaching-learning activity. When English teachers are engaged in reflection, they automatically will affect about reflection-inaction, on-action, and for-action. The feedback got in reflective practice can be applied as a standard to get some solutions from teaching trouble/problem and increase teaching practice. It occasionally presents some pedagogical components in classroom activity such as technique, classroom management, students' achievement, and students' behavior/attitude.

Moreover, implementing reflective teaching in teaching guides the teacher for becoming a reflective teacher in which the approach of teacher's thinking and the thinking outcome seems highly be more coherent and assurance because what teacher utters and what teacher does after practicing reflective teaching is based on the substantiation. Hence, teachers can consider some beneficial techniques to lead the students to understand and master in English. Thus, a teacher can also judge how good students' capability and ability in using English both spoken and written. Directed by the teacher diary, a teacher seems highly to acquire a large chance to examine every student's skill and the problems faced by the student in learning English. In this phase, teacher has the main role to solve the problems and find the solutions. Therefore, teacher has an opportunity to develop professionalism by utilizing reflective teaching especially the teacher's journal in teaching practice. To sum up, English teachers need to do reflection due to the beneficial impact on teacher quality.

\section{Acknowledgments}

The researchers gratefully acknowledge the participant support for this project is from an in-service EFL teacher in one of Junior High Schools in Bandar Lampung.

\section{References}

Astika, G. (2014). Reflective teaching as alternative assessment in teacher education: A case study or pre-service teachers. TEFLIN Journal, 16-32.

Azizah, e. a. (2018). In-Service English Teacher's Perceptions of Reflective Teacher Diary to Promote Professional Development. International Journal of Multicultural and Multireligious Understanding, 1-8.

Bailey, K. M., \& Nunan, D. (2001). Persuing professional development: The self as source. Teaching English as a Second or Foreign Language. 
Chien, C. (2013). Analysis of a language teachr's journal of classroom practice as reflective practice. Reflective Practice, 131-143.

Degago, A. T. (2007). Using reflective journals to enhance impoverished practoicum placements: A case in teacher education in Ethiopia. Teach. Educ, 343-356.

Desimone, L. M. (2009). Improving impact studies of teachers' professional development: Toward better conceptualizations and measures. Educational Research, 181-199.

Dewey, J. (1933). How we think. Lexington: DC Health.

Farrell, T. S. (2004). Reflective practice in action. Thousand Oaks: CA: Corwin Press.

Farrell, T. S. (2007). Reflective language teaching: From theory to practice. London and New York: Continuum.

Farrell, T. S. (2012). Reflecting on reflective practice: $(\mathrm{Re})$ Visiting Dewey and Schon. TESOL Journal, 7-16.

Farrell, T. S. (2015). Promoting teacher reflection in second language education: A framework for TESOL professionals. New York: Routledge.

Guskey, T. R. (2000). Evaluating professional development. Thousand Oaks: CA: Corwin Press.

Lee, I. (2007). Preparing pre-service English teachers for reflective practice. ELT Journal, 321-329.

Lyons, N. (2010). Handbook of Reflection and Reflective Inquiry. New York: Springer Science Business Media.

Miles, M. B., Huberman, A. M., \& Saldana, J. (2014). Qualitative data analysis: a Methods sourcebook. USA: Sage Publications, Inc.

Moradkhani, S., Akbari, R., Ghafar Samar, R., \& Kiany, G. R. (2013). English language teacher educators' pedagogical knowledge base: The macro and micro categories. Australian Journal of Teacher ducation.

Orlan-Barak, L., \& Yinon, H. (2005). Sometimes a novice and sometimes an expert: Mentor's professional expertise as revealed through their stories of critical incidents. Oxford Review of Education.

Sari, P., Palangngan, S. T., Mulyaningsih, E., Samritin, \& Rahman, F. (2019).

Environmental expression using discourse analysis. IOP Conference

Series: Earth and Environmental Science, 343(1).

https://doi.org/10.1088/1755-1315/343/1/012149

Schon, D. A. (1983). The Reflective Practitioner: How professionals think in action. New York: Basic Books.

Soisangwarn, A. \& Wongwanich, S. (2014). Promoting the Reflective Teacher through Peer Coaching to Improve Teaching Skills. Procedia-Social and Behavioral Sciences, 2504-2511. 
Tosriadi, e. a. (2018). Peer Observation as a Means to Develop Professionalism. International Journal of Multicultural and Multireligious Understanding, 151-158.

Yin, R. K. (2018). Case Study Research \& Applications: Design and Methods (6th Ed). California: SAGE Publications. 